Western University

Scholarship@Western

2012

Peter Dickinson World Stages, Local Audiences: Essays on Performance, Place, and Politics

Kim Solga

The University of Western Ontario, ksolga@uwo.ca

Follow this and additional works at: https://ir.lib.uwo.ca/englishpub

Part of the English Language and Literature Commons

Citation of this paper:

Solga, Kim, "Peter Dickinson World Stages, Local Audiences: Essays on Performance, Place, and Politics" (2012). Department of English Publications. 189.

https://ir.lib.uwo.ca/englishpub/189 


\section{PETER DICKINSON}

World Stages, Local Audiences: Essays on Performance, Place, and Politics.

Theatre: Theory Practice Performance.

Manchester: Manchester UP, 2010. Hb 272pp.

\section{KIM SOLGA}

Peter Dickinson's World Stages, Local Audiences is a book I really, really wanted to like. It takes significant risks in style and structure. It is personal and invested. It is compelled by the same kinds of questions-about political performance, social justice, community affect, and cultural change-that motivate a great deal of my own work. It is relentlessly eclectic in its choice of primary sources, examining everything from the Beijing and Vancouver Olympics to the drama of Tony Kushner to the media spectacles of professional soccer. It is a scholarly nomadology (136-175) - a term I suspect Dickinson won't mind me applying here-as well as a book with real heart. And yet, for all that, it doesn't really work.

That does not, however, mean you should not read it. As a document of contemporary performance and as a thoughtful exegesis of the kinds of ethical struggles that mark so much of our labour in the peripatetic discipline(s) of theatre and performance studies, it is one of the most comprehensive texts I've encountered in a long time. Dickinson begins by marking his debt to a variety of scholars that readers will not be surprised to find among the book's fellow travelers-including Jill Dolan, David Román, and José Muñoz-and suggests that his project in the book will be to think through the ways in which "events played out on the world stage (wars, acts of terror, religious gatherings, natural disasters, sporting contests, human-rights protests) can never be interpreted apart from the local constituencies to whom and through whom they are being mediated," while also considering some of the ways in which local works speak (effectively and politically) to global urgencies (7). He then attempts to walk the talk in four chapters and a coda that develop these central concerns in remarkably different ways: by comparing "Olympic showcases" and other cultural engagements with the games (chapter one); by reading the politicized spectacles of same-sex marriage "in North America and beyond" (chapter two); by reading Tony Kushner through David Beckham's global wanderings (chapter three); by thinking about queer mourning through the work of two women artists (Paula Vogel and Margie Gillis) whose brothers died of AIDS (chapter four); and by encountering his own limits as a spectator in the face of climate change (in the coda). 
The problem with this approach is probably pretty clear: it is way too vast to make a cohesive book. As a reviewer, I read this text in a condensed period of time and thus approached it as a monograph; in hindsight, I see this was an error. World Stages is not a monograph, after all; it is a collection of essays, and it needs to be read this way, by dipping in and out. Once I realized that I should take my cue from Dickinson's own "travelogue" (137) style I found I enjoyed all he had to offer much more.

Dickinson is at his best when writing about local performance, and I cheered to see so much of what is excellent about Vancouver's performance scene both lauded and critiqued seriously under his care. From The Cultch to Boca del Lupo to the works of former students played out on street corners, Dickinson charts the city's strengths as a Pacific coast culture hub. At the same time, referencing multiple major plays he saw staged in Vancouver by local companies, he reminds his scholarly readers that so much of what we are able to do in our jobs as performance critics relies on an upper-middle-class mobility, our ability to travel to see important international performance. Although Dickinson does chart his international spectatorship throughout the book, by also emphasizing so much Vancouver performance he affirms that a scholarly career can, and perhaps should, be built first on what we see in our own backyards.

The book's weakest links are those collisions that prove more strange than satisfying. The chapter on Kushner and Beckham is really two different essays awkwardly interwoven: one about Kushner in relation to Canada's military deployment in Afghanistan; the other about professional sport, "global" star power, and the media frenzy that follows the best athletes around the world. The chapter on Beijing's and Vancouver's separate Olympics doesn't quite work because Vancouver had yet to happen when the book came out; something important thus seems to be missing from the analysis. The strongest work by far appears in Dickinson's chapter on samesex marriage; the chapter on queer mourning, while offering some very strong readings of exciting performance work, doesn't move theoretically much beyond the already canonical writings of Dolan, Román, and later Judith Butler.

Finally — and fittingly, perhaps, given how conflicted I feel about this book-the thing I like most about World Stages, Local Audiences is also the thing that drove me the most crazy while reading it. Dickinson writes in a very personal way: he names all the people who see theatre with him; he talks about students and friends of students who guide him around the world; he tells you about the pre-theatre dinner. It's sincere, I believe, but it reads as indulgent. (The problem is 
compounded by a general lack of editorial rigour throughout: Dickinson over-uses filler phrases that ought to have been chopped; the book is also longer than it needs to be.) And yet Dickinson is not wrong when he reminds me that "scholars who work in cross-disciplines such as cultural studies and performance studies are not always comfortable with [...] the mixing of the personal and the professional, the social and the scholarly, the theatrical and the touristic" (137), and I admire the challenge he poses in response. I will, therefore, not be predictable and scold Dickinson for how-dare-he, but rather applaud him for his daring - for daring to expose, and also to revel in, the very things that make our work possible (like travel, like leisure, like money, like talented friends-of-friends). If Dickinson errs too enthusiastically in this work, so be it. His book sets an important precedent for talking out loud about the class privilege that attends academic privilege; more of us should try it some time.

\section{ÉRIC MÉCHOULAN}

Doù nous viennent nos idées? Métaphysique et intermédialité.

Montréal : vlb éditeur, 2010. 288pp.

\section{ANDRÉ LOISELLE}

As director of the "Centre de recherche sur l'intermédialité," at the Université de Montréal, Éric Méchoulan is fully aware that a fashionable buzzword like "intermedialty" runs the risk of quickly becoming a trendy piece of pseudo-academic jargon emptied of any significance through overuse and misuse by facile scholars and sophomoric students. He says so himself, early in his book Doù nous viennent nos idées? Métaphysique et intermédialité (35). The fear of vulgarization implicitly underlies Méchoulan's project. On the surface, the purpose of this study is to show that ideas are not merely conveyed by various media (oral language, the written word, the printed press, etc.); rather, they are in fact engendered and shaped by the media that perform these epistemological transmissions (29-31). Five pages into the introduction Méchoulan states the obvious: "One should not think that the institutional materiality and form of these transmissions has no effect on ideas and discourses" (17, my translation). However, beneath this assertion, which would not surprise anyone who has read McLuhan (as Méchoulan obviously has: 43), what the author really wants to present is a thorough demonstration that intermediality is anything but a facile, trendy, sophomoric concept.

Over the 245 pages of this rich and sometimes engaging book, 